\title{
IDENTIFIKASI KAPANG PADA KECAP KEDELAI MANIS PRODUKSI LOKAL KEDIRI DENGAN METODE PENGENCERAN
}

\author{
D.Humairoh \\ ${ }^{1}$ Jurusan Biologi, Fakultas Sains \\ Institut IImu Kesehatan Bhakti Wiyata \\ Kediri, Indonesia \\ e-mail: durrohhumairoh@gmail.com
}

\begin{abstract}
Abstrak
Kecap kedelai merupakan salah satu produk fermentasi yang telah dikenal sejak ribuan tahun yang lalu di berbagai negara termasuk Indonesia. Kecap kedelai manis merupakan produk kecap kedelai yang menjadi produk khas Indonesia. Berbagai jenis kecap yang dijual di pasar merupakan produk industri kecap dalam negeri atau produksi lokal dengan harga yang relatif murah sehingga dikhawatirkan kualitas bahan dasar kurang bagus serta sanitasi selama proses produksinya kurang terjaga. Keamanan pangan dapat dipengaruhi oleh beberapa faktor pencemar antara lain cemaran mikrobiologis, logam berat, dan bahan kimia yang membahayakan kesehatan.Tujuan penelitian ini adalah untuk mengetahui jumlah kapang dan jenis kapang yang ditemukan pada sampel kecap produk lokal Kediri. Penelitian ini menggunakan metode pengenceran hingga $10^{1}$ yang terdiri dari 10 sampel kecap kedelai manis produksi lokal Kediri dengan merek yang berbeda. Hasil pengamatan dari pengenceran kecap menunjukkan bahwa pada sampel kecap kedelai manis produk lokal Kediri ditemukan jumlah kapang sebanyak $<50 \mathrm{koloni} / \mathrm{mL}$ pada setiap sampelnya dan jenis kapang yang ditemukan meliputi Penicillium sp., Aspergillus sp., Rhizopus sp., dan Mucor sp. sehingga dapat disimpulkan bahwa kecap produksi Kediri aman dikonsumsi karena sesuai standar yang ditetapkan Pemerintah dalam SNI 3543: 2013.
\end{abstract}

Kata kunci: Jumlah koloni, Jenis kapang, Kecap kedelai manis, produk lokal Kediri

\begin{abstract}
Soy sauce was one of fermentation products that had been known for thousand years in various countries including Indonesia. Sweet soy sauce was original product from Indonesia. Various kinds of sweet soy saucesold in market were local or domestic products with relatively cheap price thus its quality of basic ingredients and sanitation of production process became issues. Food safety could be affected by some factors such as microbiological contamination, heavy metals and harmful chemical substances. The purpose of this study was to determine the number and type of mold fungi found in local soy sauce of Kediri. This study used dilution method up to $10^{-1}$ for 10 samples from 10 different brands. The result shows that each sample contains $<50$ colonies/ $\mathrm{ml}$ of molds. Molds that had been found are Penicillium sp., Aspergillus sp., Rhizopus sp., and Mucor sp. It can be concluded that the local sweet soy sauce of Kediri are safe to be eaten according to standard established by Government in SNI 3543: 2013.
\end{abstract}

Keywords: The number of colonies, mold type, sweet soy soy sauce, local products Kediri 


\section{PENDAHULUAN}

Kecap kedelai merupakan salah satu produk fermentasi yang digunakan sebagai produk pencita rasa khususnya di negara Asia yang merupakan produk bumbu (condiment) yang tertua di Cina selama lebih dari 3000 tahun (Muangthai dkk.,2009). Salah satu ciri khas kecap kedelai khas Indonesia yang berbeda dengan negara lainnya adalah kecap kedelai manis. Berdasarkan SNI 01-3543-2013, kecap kedelai manis adalah produk cair yang diperoleh dari hasil fermentasi kacang kedelai (Glycine $\max$ L.) dan gula, gula merah, dengan atau tanpa proses karamelisasi dengan atau tanpa penambahan bahan lain, dengan karakteristik dasar total gula tidak kurang dari 40\% (Meutia, 2015).

Dewasa ini kesadaran masyarakat terhadap pangan, nilai gizi dan keamanan pangan semakin meningkat. Bahan makanan yang dikonsumsi menjadi perhatian khusus karena banyak penderita yang keracunan atau pencernaannya terganggu akibat makanan yang dikonsumsi telah tercemar. Berikut beberapa faktor yang dapat mempengaruhi keamanan pangan, antara lain cemaran mikrobiologis, logam berat, dan bahan kimia yang membahayakan kesehatan. Mikroorganisme pada makanan bisa berasal dari tanah, udara dan air pada proses pencucian maupun pengolahan. Keamanan pangan penting untuk menjamin pangan yang layak dan aman dikonsumsi (Deswita dkk., 2013).

Seiring dengan meningkatnya pengetahuan dan kesadaran akan kesehatan terhadap pangan yang dikonsumsi, konsumsi pangan yang aman merupakan hal yang harus diperhatikan oleh produsen dan konsumen. Berdasarkan UU Pangan No. 7 tahun 1996, keamanan pangan adalah kondisi dan upaya yang diperlukan untuk mencegah pangan dari kemungkinan cemaran biologis, kimia, dan benda lain yang dapat mengganggu, merugikan, dan membahayakan kesehatan manusia. Pangan yang aman adalah pangan yang tidak mengandung bahaya biologi atau mikrobiologi, bahaya kimia, dan bahaya fisik (Nugraheni, 2010).

Penerapan peraturan yang berkaitan dengan keamanan pangan secara benar terbukti mampu meningkatkan keamanan pangan serta dapat mengurangi cemaran fisik, kimiawi, atau biologis dalam bahan pangan. Institusi pemerintah yang bertanggung jawab terhadap peredaran produk pangan di seluruh Indonesia adalah Badan Pengawasan Obat dan Makanan (BPOM). BPOM tidak hanya melakukan pengawasan terhadap pangan tetapi juga melakukan pengawasan terhadap peredaran produk terapetik, narkotika, psikotropika, zat aktif lain, obat tradisional, kosmetik, dan bahan berbahaya (Nugraheni, 2010).

Penemuan mikroorganisme pada kecap manis produk lokal di Kota Padang oleh Deswita dkk. (2013) diperoleh hasil jenis kapang Aspergillus sp. dan Penicillium $\mathrm{sp}$ dari empat sampel dengan merek yang berbeda. Abalunan et al. (2013) melaporkan bahwa pada 6 sampel kecap berbeda merek di wilayah Diliman Filipina didapatkan kapang jenis Aspergillus sp. dan Fusarium sp. Nugraheni (2010) menyebutkan bahwa pengamatan jumlah kapang juga merupakan hal yang penting dalam pengujian kelayakan bahan pangan, pada beberapa sampel kecap manis yang dijual di wilayah Balai Besar Pengawas Obat dan Makanan (BPOM) Yogyakarta didapatkan jumlah kapang < 10 koloni/mL sehingga dapat dinyatakan aman dari cemaran mikroba jenis kapang.

Berdasarkan penelitian terdahulu bahwa pengamatan tentang kapang sangat penting untuk mendukung kelayakan uji bahan pangan sesuai standart yang telah ditetapkan oleh Pemerintah sekaligus dapat menjadi acuan mengenai sebaran kapang pada kecap kedelai manis yang tercemar. Peneliti tertarik mengamati variasi jamur yang tumbuh pada kecap produksi lokal Kediri serta menentukan kualitas kecap berdasarkan cemaran mikroba jenis kapang menurut SNI 3543: 2013 yang telah ditetapkan oleh Pemerintah Republik Indonesia.

\section{METODE PENELITIAN}

Penelitian dilakukan di Laboratorium Mikologi Institut IImu Kesehatan Bhakti Wiyata Kediri pada bulan Januari 2017. Rancangan dalam penelitian ini adalah deskriptif observasional. Variabel bebas 
dalam penelitian ini adalah berbagai macam kecap produksi lokal Kediri. Variabel terikat meliputi jenis jamur yang tumbuh dan jumlah koloni yang tumbuh setelah 7 hari masa inkubasi berdasarkan SNI 01-3543-2013. Sedangkan variabel kontrolnya meliputi suhu penyimpanan $20-25^{\circ} \mathrm{C}$, lama inkubasi perlakuan, volume kecap $10 \mathrm{~mL}$, volume sampel $1 \mathrm{~mL}$ pada masing-masing cawang, kecap hanya diperoleh di wilayah Kediri. Kecap yang digunakan untuk sampel adalah 10 macam kecap lokal produksi Kediri dengan merk yang berbeda.

\section{Alat dan Bahan \\ Alat}

Alat-alat yang di gunakan dalam penelitian ini meliputi cawan petri, tabung reaksi, gelas beaker, gelas ukur, erlenmeyer, pipet steril, autoclave, lampu spiritus, batang pengaduk, timbangan digital, coloni counter, vortex, mikropipet, blue tip, jarum ose, inkubator, lampu spiritus, tissu, kapas, alumunium foil, kertas wrap, dan kamera digital sebagai alat dokumentasi.

\section{Bahan}

Bahan-bahan yang digunakan dalam penelitian ini adalah kecap manis, aquades, alkohol 70\%, kertas label, media Saboroud Dextrose Agar (SDA).

\section{Prosedur Penelitian}

A. Pengumpulan sampel penelitian (Deswita dkk., 2013)

Sampel kecap yang digunakan berasal dari produksi lokal Kediri. Setelah melakukan survey di seluruh pasar yang tersebar di wilayah Kediri, terdapat 10 sampel kecap dengan merk yang berbeda.

B. Pembuatan media pertumbuhan

Media pertumbuhan kapang yang digunakan adalah Saboroud Dextrose Agar (SDA). SDA merupakan media yang baik untuk menumbuhkan kapang atau yeast yang patogen atau non patogen.

C. Pengujian kapang

Eksplorasi jamur pada kecap produk lokal Kediri dilakukan menggunakan metode pengenceran. Homogenisasi sampel dan pengenceran dilakukan pada $10^{1}$. Setiap sampel pada pengenceran $10^{1}$ diambil sebanyak $1 \mathrm{~mL}$ kemudian SDA dituangkan sebanyak 15-20 mL di simpan pada suhu kamar dan dilakukan pengamatan setelah 7 hari masa inkubasi. Sampel pada penelitian ini menggunakan 10 macam kecap dengan melakukan pengulangan sebanyak 3 kali. Pada hari ke-7 dilakukan identifikasi menggunakan buku Samson (1988). Kemudian dilakukan perhitungan koloni kapang yang tumbuh.

D. Pengolahan data

Jumlah koloni yang tumbuh pada pengenceran $10^{1}$ di rata-rata sesuai SPC. Sehingga didapatkan hasil jumlah koloni/ml yang akan di bandingkan dengan minimal cemaran kapang pada kecap kedelai sesuai SNI 01-3543-2013.

\section{HASIL DAN PEMBAHASAN}

\section{A. Jumlah koloni kapang yang tumbuh}

Uji kapang yang tumbuh pada semua sampel kecap produksi lokal Kediri menunjukkan hasil yang termasuk aman untuk konsumsi karena tidak melebihi standar minimal cemaran mikroba khususnya kapang pada kecap kedelai manis yang di tetapkan oleh Pemerintah.

Standar Nasional Indonesia untuk kecap kedelai manis yang tercantum pada SNI 3543: 2013 dapat dapat dilihat pada Tabel 1. 
Tabel 1. Syarat mutu kecap kedelai manis SNI 3543: 2013

\begin{tabular}{|c|c|c|c|}
\hline No & Kriteria Uji & Satuan & Persyaratan \\
\hline 1 & Keadaan & & \\
\hline 1.1 & Bau & - & Normal, khas \\
\hline 1.2 & Rasa & - & Normal, khas \\
\hline 2 & Kadar protein $(\mathrm{Nx6,25)}$ & $\%(b / b)$ & $\min .1,0$ \\
\hline 3 & $\begin{array}{l}\text { Kadar gula (dihitung sebagai } \\
\text { sakarosa) }\end{array}$ & $\%(b / b)$ & $\min .30$ \\
\hline 4 & $\mathrm{pH}$ & - & $3,5-6,0$ \\
\hline 5 & Cemaran logam & & \\
\hline 5.1 & Timbal $(\mathrm{Pb})$ & $\mathrm{mg} / \mathrm{kg}$ & maks. 1,0 \\
\hline 5.2 & Kadmium (Cd) & $\mathrm{mg} / \mathrm{kg}$ & maks 0,2 \\
\hline 5.3 & Timah (Sn) & $\mathrm{mg} / \mathrm{kg}$ & maks 40,0 \\
\hline 5.4 & Merkuri (Hg) & $\mathrm{mg} / \mathrm{kg}$ & maks 0,05 \\
\hline 6 & Cemaran arsen (As) & $\mathrm{mg} / \mathrm{kg}$ & maks 0,5 \\
\hline 7 & Cemaran mikroba & & \\
\hline 7.1 & Bakteri coliform & $\mathrm{APM} / \mathrm{g}$ & $<3$ \\
\hline 7.2 & Kapang & koloni/g & maks. 50 \\
\hline 8 & Aflatoksin & & \\
\hline 8.1 & $\mathrm{~B}_{1}$ & $\mu \mathrm{g} / \mathrm{kg}$ & maks. 15 \\
\hline 8.2 & Total aflatoksin & $\mu \mathrm{g} / \mathrm{kg}$ & maks. 20 \\
\hline
\end{tabular}

Secara garis besar untuk kriteria mutuyang terdapat pada kecap kedelai manis terbagi menjadi 3 kelompok besar yaitu kriteria mutu secara organoleptik, mutu secara kimia, dan mutu secara mikrobiologis. Untuk kriteria mutu kecap kedelai manis meliputi kadar protein, kadar gula, dan $\mathrm{pH}$. Kandungan protein merupakan parameter kualitas kecap manis(Direktorat Gizi Depkes RI, 1996).
Pada SNI kecap kedelai sebelumnya (SNI 3543 - 1999) tertulis bahwa kadar protein kecap kedelai manis adalah minimal 2,5\% dan minimal $4 \%$ untuk kecap kedelai asin, dengan pertimbangan bahwa kecap kedelai manis sudah ditambahkan dengan gula dan bumbu-bumbu lainnya (Purwoko dan Handajani, 2007). Tabel 2 merupakan hasil jumlah koloni pada kecap produk lokal Kediri dengan metode pengenceran $10^{1}$.

Tabel 2. Jumlah koloni kapang yang tumbuh dari sampel kecap produk lokal Kediri

\begin{tabular}{cc}
\hline Nomor Sampel Kecap & Rata-rata Jumlah Koloni Kapang (Koloni/mL) \\
\hline 1 & 16 \\
2 & 10 \\
3 & 23 \\
4 & 29 \\
5 & 26 \\
6 & 22 \\
7 & 33 \\
8 & 42 \\
9 & 19 \\
10 & 12 \\
\hline
\end{tabular}

Hasil tersebut menunjukkan bahwa jumlah koloni kapang kurang dari $50<50$ koloni/g), artinya kecap produk lokal Kediri telah memenuhi standar dan aman untuk dikonsumsi sesuai SNI kecap kedelai manis pada Tabel 1.

Nugraheni (2010) menyebutkan bahwa uji angka kapang pada kecap yang terdapat di wilayah Yogyakarta telah terbukti aman dengan rata-rata jumlah koloni < 10 koloni/g. Pemeriksaan cemaran mikroba terutama kapang sangat penting untuk dilakukan karena adanya kapang dalam bahan pangan dapat mempengaruhi umur simpan dan penurunan kualitas produk hasil olahan pangan tersebut. 
Kadar gula yang terkandung pada kecap kedelai manis ditetapkan minimal sebesar $30 \%$ untuk mengelompokkan kecap kedelai sebagai kecap kedelai manis. Uji kadar gula dari beberapa produsen kecap di Indonesia yang dianalisis di BBIA.
Berdasarkan hasil analisis produk kecap kedelai manis di Indonesia memiliki ratarata kadar gula sekitar $60,38 \%$. Tabel 3 menunjukkan hasil uji kadar gula dari beberapa produsen kecap di Indonesia yang dianalisis BBIA (Meutia, 2015).

Tabel 3. Hasil analisis kadar gula kecap kedelai manis beberapa produsen kecap di Indonesia (Meutia, 2015)

\begin{tabular}{cc}
\hline Contoh Kecap Kedelai Manis & Kadar Gula (sebagai Sakarosa) dalam \% \\
\hline Kecap Kedelai Manis 1 & 63,7 \\
Kecap Kedelai Manis 2 & 64,0 \\
Kecap Kedelai Manis 3 & 30,2 \\
Kecap Kedelai Manis 4 & 51,7 \\
Kecap Kedelai Manis 5 & 32,5 \\
Kecap Kedelai Manis 6 & 67,5 \\
Kecap Kedelai Manis 7 & 67,4 \\
Kecap Kedelai Manis 8 & 64,9 \\
Kecap Kedelai Manis 9 & 64,7 \\
Kecap Kedelai Manis10 & 65,1 \\
Kecap Kedelai Manis11 & 64,2 \\
Kecap Kedelai Manis12 & 65,6 \\
Kecap Kedelai Manis13 & 65,8 \\
Kecap Kedelai Manis14 & 65,6 \\
Kecap Kedelai Manis15 & 65,7 \\
Kecap Kedelai Manis16 & 66,4 \\
Kecap Kedelai Manis17 & 66,4 \\
Kecap Kedelai Manis18 & 66,5 \\
Kecap Kedelai Manis19 & 66,3 \\
Kecap Kedelai Manis20 & 66,3 \\
Kecap Kedelai Manis21 & 66,2 \\
Kecap Kedelai Manis22 & 22,2 \\
Kecap Kedelai Manis23 & 66,9 \\
Rata-rata kadar gula & 60,38 \\
\hline
\end{tabular}

Kadar gula pada kecap kedelai menjadi pembeda antara kecap kedelai manis dan kecap kedelai asin. Kecap kedelai manis memiliki kadar gula yang lebih tinggi dibandingkan kecap kedelai asin yang mengandung gula sekitar $0,4 \%$ saja, bahkan pada beberapa produk kecap kedelai asin tidak terdapat kandungan gula.Hidayat dan Sri (2006) menyebutkan bahwa pada akhir proses produksi kecap asin tidak ada penambahan gula. Sedangkan pada pembuatan kecap manis dilakukan penambahan gula serta bumbubumbu pada sari fermentasi kedelai. Pada SNI 3543:2013 ditetapkan bahwa kadar gula minimal untuk kecap kedelai manis adalah 40\%, namun mengingat pada contoh uji kecap kedelai terdapat kecap kedelai yang kadar gulanya kurang dari $40 \%$ maka untuk mengakomodir semua contoh kecap kedelai manis di Indonesia ditetapkan bahwa kadar gula kecap kedelai manis minimal $30 \%$. Kadar gula pada kecap kedelai manis lebih terkait pada kualitas organoleptik dari kecap kedelai manis, sehinggabesar kadar gula pada kecap kedelai manis mempengaruhi penerimaan konsumen terhadap kecap kedelai manis (Meutia, 2015).

Bukan hanya berpengaruh pada kualitas mutu organoleptik, kadar gula yang tinggi juga berkaitan erat dengan tinnginya koloni kapang yang terdapat pada kecap. Peningkatan jumlah kapang akan signifikan karena kapang mempunyai kemampuan hidup pada konsentrasi dengan kadar gula yang tinggi. Semakin banyak kandungan gula dalam kecap maka semakin tinggi pula kandungan kapang didalamnya. Konsentrasi gula yang 
yang tinggi dalam kecap sedikit demi sedikit dihidrolisis oleh kapang untuk pertumbuhannya. Gula berkurang sementara jumlah kapang terus meningkat (Hendritomo, 2015). Hal ini sesuai dengan hasil pengamatan pada kecap produk lokal Kediri bahwa pada sampel 7 dan 8 memiliki tekstur sangat kental karena banyaknya kandungan gula didalam kecap tersebut sehingga jumlah koloni kapang (33 dan 42) yang ditemukan dengan jumlah yang cukup tinggi dibandingakan dengan sampel yang lain (Tabel 2).

Pada fermentasi yang terjadi pada kecap yang meliputi fermentasi jamur (koji) maupun fermentasi dalam larutan garam (moromi) terjadi perubahan-perubahan biokimiawi oleh aktifitas enzim yang dihasilkan oleh mikroba (baik bakteri maupun kapang atau khamir). Pada fermentasi jamur (koji), mikroba yang dominan adalah Aspergillus soyae(Meutia, 2015).Selama proses fermentasi koji, protein yang terkandung dalam kedelai akan dipecah menjadi peptida dan asam amino oleh enzim proteolitik, terutama dari jenis protease netral dan basa. Selain itu, Aspergillus soyae juga mensekresikan enzim a-amilase yang berfungsi untuk menghidrolisis polisakarida menjadi oligosakarida, disakarida dan monosakarida. Enzim lipase yang dapat memecah lipid juga ditemukan ketika proses fermentasi koji berlangsung (Fayyad, 2008).

Pada kecap juga di tambahkan garam. Konsentrasi garam yang optimal 17 sampai $19 \%$ berpengaruh terhadap hidrolisis protein dalammoromi dan kecepatan pembentukan asam laktat dan alkohol. Mikroba utama adalah jamur Aspergillus soyae, bakteri-bakteri asam laktat yang bersifat homo fermentatif, Pseudomonas cerevisae atau Pseudomonas soyae dan khamir yang toleran terhadap garam tinggi terutama Saccharomycesrouxii. Menurut Sakaguchi dalam Kasmidjo(1990), pada konsentrasi garam yang lebih tinggi 20-30\% Pseudomonas soyae tetap tumbuh baik dan menghasilkan asam laktat tinggi sehingga dapat menurunkan $\mathrm{pH}$ sampai 4,9 , bakteri tersebut berperan dalam pembentukan cita rasa dana roma spesifik untuk kecap. Pada kondisi aerob dalam konsentrasi garam tinggi khamir yaitu Saccharomycesrouxii mengubah sejumlah glukosa (50\%) menjadi gliserol, merupakan komponen penting pendukung cita rasa kecap. Menurut Suprapti(2005), gula kelapa yang ditambahkandiperlukan dalam pembuatan kecap manis, berfungsi sebagai pemanis sehingga jumlah gula kelapa yang ditambahkan dapat berpengaruh pada respon rasa kecap organik (Meutia, 2015).

Mutu kecap akan terjaga jika dilakukan usaha-usaha untuk menekan jumlah cemaran kapang yang ada. Hal ini dapat dilakukan dengan cara mengayak butiran kedelai setelah dikeringkan atau dicuci serta dilakukan penyaringan sebelum akhir proses pembuatan kecap (Hendritomo, 2015). Dengan kata lain, bahwa mutu kecap akan terjamin selama proses produksi kualitas kedelai menjadi prioritas utama.

\section{B. Jenis jamur yang tumbuh}

Hasil penelitian uji kapang beberapa produk kecap manis produksi lokal Kediri mendapatkan beberapa jenis kapang disajikan pada Tabel 4.

\begin{tabular}{cc} 
Tabel 4. Jenis kapang yang ditemukan pada sampel kecap produk lokal Kediri \\
\hline Nomor Sampel Kecap & Jenis Kapang \\
\hline 1 & Penicillium $\mathrm{sp}$. \\
2 & Aspergillus sp.; Mucor sp. \\
3 & Penicillium sp.; Rhizopus $\mathrm{sp}$. \\
4 & Aspergillus sp. \\
5 & Aspergillus sp. \\
6 & Mucor $\mathrm{sp}$. \\
7 & Aspergillus sp.; Rhizopus sp. \\
8 & Aspergillus sp.; Mucor $\mathrm{sp}$. \\
9 & Aspergillus sp.; Rhizopus $\mathrm{sp}$. \\
10 & Aspergillus sp.; Penicillium $\mathrm{sp}$. \\
\hline
\end{tabular}


Berbagai jenis kapang ditemukan pada beberapa sampel kecap kedelai manis produksi lokal Kediri yaitu Penicillium sp., Aspergillus sp., Rhizopus sp., dan Mucor sp. Hasil ini seperti halnya yang ditemukan oleh Deswita dkk. (2013) bahwa pada sampel kecap produk lokal Padang ditemukan jenis kapang yang hampir sama yaitu dari jenis Penicillium sp. dan Aspergillus sp. Abalunan et al. (2013) juga menemukan Aspergillus sp. dan Fusarium sp. pada 6 sampel produk kecap yang dikumpulkan di Lanao del Norte, Filipina. Menurut Hendritomo (2015) bahwa jenis kapang yang banyak dijumpai pada kecap produksi Indonesia meliputi Aspergillus spp.,Penicillium purpurogenum, Rhizopus oryzae, Eurotium spp.

Untuk batasan cemaran mikrobiologis komoditas kecap kedelai manis mengikuti regulasi yang terdapat pada BPOM. Berdasarkan Peraturan Kepala BPOM Republik Indonesia No. HK.00.06.1.52.4011 Tahun 2009 tentang Penetapan Batas Maksimum Cemaran Mikroba dan Kimiadalam Makanan, batasan cemaran mikroba untuk kecap kedelai manis adalah maksimum <3 APM $/ \mathrm{mL}$ untuk koliform dan kapang maksimum 50 koloni/g (Dewanti, 2012). Meskipun proses pembuatan kecap kedelai menggunakan kapang, namun cemaran kapang tetap dibatasi pada proses pembuatan kecap kedelai. Proses pemasakandapat mereduksi jumlah kapang yang terdapat pada cairan fermentasi kecap tersebut.Pembatasan jumlah kapang tersebut sanga tpenting mengingat bahwa kapang berpotensi untuk dapat menghasilkan aflatoksin yang

membahayakan bagi tubuh (Meutia, 2015).

Kontaminasi dari Genus Aspergillus sangat luas sebarannya dengan berbagai macam warna (hijau, kuning, jingga, hitam, atau coklat), secara keseluruhan warna tersebut berasal dari warna konidianya. Keberadaan Aspergillus sp. pada sampel kecap manis dapat muncul dari bahan dasar kecap yaitu kedelai baik pada sebelum panen atau pasca panen dan dapat berasal dari udara karena pada dasarnya kapang jenis ini mudah tumbuh pada semua substrat dan Aspergillus sp. juga merupakan produsen utama dari aflatoksin (Deswita dkk, 2013). Abalunan et al. (2013) menyebutkan bahwa Aspergillus sp. dapat memproduksi toksin dalam jumlah yang tinggi. Produksi toksin dari kapang pada sampel kecap dapat menginfeksi manusia selama penyimpanan dan proses produksi tidak dilakukan sesuai standar.

Batas maksimum cemaran total aflatoksin pada kecap kedelai manis adalah $20 \mathrm{ppb}$ dan batas maksimum aflatoksin B adalah $15 \mathrm{ppb}$. Hal ini telah sesuai dengan Peraturan BPOM No.HK. 00.06.1.52.4011. Aflatoksin dapat terbentuk sebagai hasil metabolit dari kapang penghasil aflatoksin serta kontaminasi kapang yang mungkin dapat berasal dari bahan baku dan gudang penyimpanan, bila tidak disimpan dengan baik. Karena itu dalam pemilihan kapang atau jamur yang digunakan pada pembuatan kecap adalah jamur yang bukan pembentuk aflatoksin perlu dijadikan bahan pertimbangan dalam produksi kecap kedelai (Meutia, 2015).

Aflatoksin yang terkandung pada beberapa kapang seperti Aspergillus parasiticus, Aspergillus flavus, Aspergillus oryzae, dan Aspergillus soyae merupakan faktor pendukung untuk memperkuat kontaminasi makanan mulai dari tahap penyetokan, pengolahan, dan penyimpanan disamping kelembaban dan kebersihan tempat penyimpanan makanan tersebut (Chang et al., 1995: Bennet et al., 2003).

Kun-young dkk., (1988) melaporkan bahwa selama proses fermentasi berlangsung, produksi aflatoksin lebih banyak pada kondisi yang menggunakan kultur campuran. Produksi aflatoksin G1 sangat mudah terstimulasi dan dapat terdegradasi dengan cepat, sedangkan aflatoksin B1 sangat lambat pembentukannya. Jumlah total aflatoksin yang terdapat pada proses fermentasi yang disimulasikan dengan Aspergillus parasiticus menunjukkan bahwa selama proses pematangan meju (makanan fermentasi kedelai asal Korea) terjadi degradasi aflatoksin secara signifikan, serta terjadi peningkatan degradasi aflatoksin pada fermentasi yang melibatkan arang aktif pada campuran fermentasi. Hal ini dapat menunjukkan 
bahwa selama proses fermentasi kecap kedelai dilangsungkan secara terkendali, dalam artian suhu proses yang terkendali serta mencegah adanya kontaminasi silang dari bahan baku atau lingkungan proses produksi, maka jumlah aflatoksin yang terdapat pada kecap kedelai harus memenuhi persyaratan yang telah ditetapkan oleh BPOM.

Pada pengamatan kapang pada kecap produk lokal Kediri diperoleh banyak dari jenis Aspergillus.sp dan Rhizopussp. $\mathrm{Hal}$ ini sangat memungkinkan karena pada dasarnya proses fermentasi kecap terdiri dari 2 tahap yang membutuhkan kedua jenis kapang tersebut, yaitu fermentasi padat (fermentasi koji/tempe) dan fermentasi cair (fermentasi moromi). Kapang yang digunakan dalam fermentasi padat adalah Aspergillus sp. dan Rhizopus sp.Fermentasi padat memerlukan waktu selama 3-5 hari. Hasil fermentasi padat disebut koji jika menggunakan Aspergillus sp., tetapi disebut tempe jika menggunakan Rhizopus sp. (Rahayu dkk., 2005).

Keberadaan Penicillium sp. selalu dikaitkan dengan keberadaan Aspergillus sp. karena keduanya merupakan indikator kontaminasi kapang pada makanan (Deswita dkk, 2013). Oleh karena itu, pada sampel kecap ini, ditemukan banyak Aspergillus sp. dengan Penicillium sp. yang bersama-sama.

Penicillium sp. yang ditemukan pada pengamatan kali ini adalah genus Penicillium dengan koloni berwarna biru pekat. Pada peneltian Deswita dkk. (2013) melaporkan bahwa ditemukan dua jenis genus Penicilliumyakni Penicillium citrinum dan Penicillium chrysogenum. Pada pengamatan makroskopis Penicilliumcitrinum di hari pertama koloninya berwarna putih, pada hari ke tiga warna koloninya berubah menjadi hijau. Setelah 7 hari masa inkubasi, warnanya berubah lagi menjadi hijau kemerahan. Warna merah tersebut terjadi karena adanya reaksi metabolisme. Sedangkan pada pengamatan makroskopis yang disebut Penicillium chrysogenum memiliki ciri-ciri warna koloni awal putih, setelah tiga hari koloni berubah menjadi biru dan pada hari ke-tujuh warna koloni menjadi biru pekat. Keberadaan genus Penicillium selalu dikaitkan dengan keberadaan genus Aspergillus, keduanya merupakan kapang sebagai indikator kontaminasi pada makanan.

Berbeda dengan khamir dan bakteri, kapang adalah organisme multiselular, oleh karena itu dapat dilihat tanpa bantuan alat seperti mikroskop, karena sudah dapat dilihat dengan mata telanjang bentuk makroskopisnya. Meskipun demikian, pengamatan dengan mikroskop binokuler lebih disarankan supaya struktur mikroskopisnya dapat diamati dengan jelas.Cara tumbuhnya kapang yaitu memperpanjang hifa dan menembus substrat. Pada beberapa bagian hifa terlihat ada pembentukan spora baik secara seksual maupun aseksual. Satu hifa dapat menghasilkan beribu-ribu spora aseksual yang tahan terhadap perubahan lingkungan, seperti spora Aspergillus oryzae (Hendritomo, 2015). Kapang bersifat aerobik, paling banyak atau terutama tumbuh pada bagian luar permukaan bahan pangan yang tercemar. Oleh karena itu, tidak menutup kemungkinan kecap juga terkontaminasi oleh kapang.

Gambar merupakan gambar mikroskopis Rhizopus sp.,Mucor sp., dan Asperillus sp. yang ditemukan pada sampel kecap produksi lokal Kediri. 

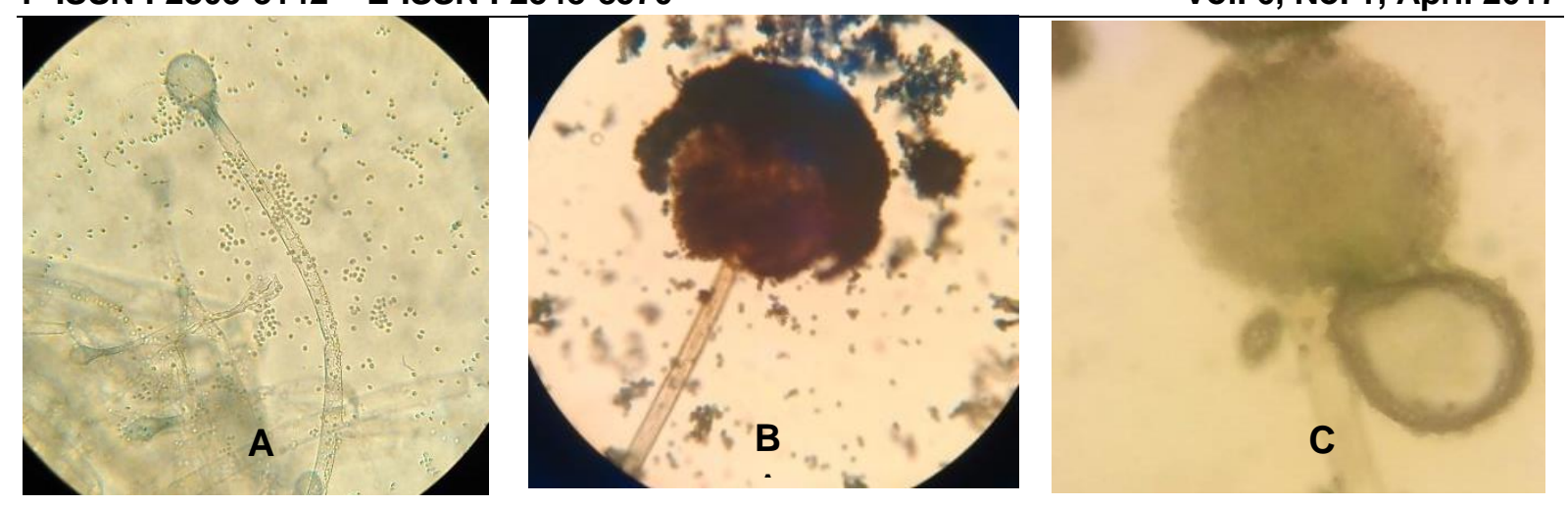

Gambar 1. Mikroskopis A) Rhizopus sp., B) Mucor sp. dan C) Aspergillus sp. (perbesaran $40 \times 10$ )

\section{Simpulan}

Simpulan dari penelitian ini bahwa jumlah koloni kapang pada sampel kecap produksi lokal Kediri aman untuk dikonsumsi karena jumlahnya $<50$ koloni $/ g$ pada setiap sampelnya sesuai dengan SNI 3543:2013 dan berbagai jenis kapang yang ditemukan dalam sampel kecap tersebut meliputi Penicillium sp., Aspergillus sp., Rhizopus sp., dan Mucor sp.

\section{Saran}

Perlu dilakukan uji lanjutan cemaran mikroba bakteri coliform, cemaran logam, serta kriteria uji yang lain (keadaan bau atau rasa, kadar protein, kadar gula, kandungan aflatoksin) sehingga kelayakan kecap produksi lokal Kediri dapat dipertanggung jawabkan dengan pasti.

\section{DAFTAR PUSTAKA}

Abalunan, April J.F., Teves, Franco G., Madamba, Maria R.S.B. 2013. Isolation of Fungal Spesies and Aflatoxin Detection in Fermented Product. International Research Journal of Biological Science. 2(4): 51-54.

Bennett J.W. and M. Klich. 2003. Microbiology Review.16(3):497516.

Chang P.K., Ehrlich K.C., Yu Cleveland T.E. 1995. Increased expression ofparasiticus aflR, encoding a sequence specific DNAbinding protein, relieves nitrate inhibition ofbiosynthesis, Applied and

\section{Environmental \\ MicrobiologyJournal.}

Depkes, 1996. Daftar Komposisi Bahan Makanan. Direktorat Gizi: Jakarta. Departemen Kesehatan RI.

Deswita, F., Mades F., Nurmiati. 2013. Uji Mikrobiologis Beberapa Produk Kecap Manis Prosuksi Lokal Yang Beredar di Beberapa Pasar Kota Padang. STKIP PGRI Sumatera Barat.

Dewanti,H.R. 2012. dalamWiarsini, D.A. 2011. Bakteri IndikatorSanitasi dan Keamanan Air Minum. Diakses 15Februari 2017 darihttp://www.scribd.com/doc/656 04944/Bakteri-Indikator-SanitasiDan-Keamanan-airMinum\#scribd.

Hidayat, N. M. C, and Sri S. 2006. Mikrobiologi Industri. Andi: Yogyakarta.

Hendritomo, H.I. 2015. Pengaruh Pertumbuhan Mikroba Terhadap Mutu Kecap Selama Penyimpanan. Pusat Pengkajian dan Penerapan Teknologi Bioindustri BPPT Jakarta.

Kasmidjo, R. B. 1990. Tempe Mikrobiologi dan Biokimia Pengolahan sertaPemanfaatannya. PAU Pangan dan Gizi UGM. Yogyakarta.

Kun-young, Park, L.Kyu-Bok, L.B. Bullerman.1988. Aflatoxin Production by Aspergillusparaciticus and Its Stability During the Manufacture of Korean Soy Paste (Doenjang) and 
Soy Sauce (Kanjang) by Traditional Method. Journal of Food Protection 12: 916 - 981 .

Meutia, Y. R. 2015. Standardisasi Produk Kecap Kedelai Manis Sebagai Produk Khas Indonesia. Jurnal Standardisasi. 17(2): Hal 147-156

Muangthai, P, U. P. Suwunna, and W. Patumpai. 2009. Development Of Healthy Soy Sauce From Pigeon Pea And Soybean.Asian Journal of Food and Agro Industry Vol.2: 291 -301 .

Nugraheni, R. 2010. Laporan Magang: Analisis Mikrobiologis Abon Ikan Tuna dan Kecap. Universitas Sebelas Maret Surakarta.

Purwoko, Tj. dan N.S. Handajani. 2007.Kandungan Protein Kecap
Manis Tanpa Fermentasi Moromi Hasil FermentasiRhyzopus oryzae dan $R$. oligosporus.Biodiversitas. 8: $223-227$.

Rahayu, A., Suranto, P. Tjahjadi. 2005. Analisis Karbohidrat, Protein, dan Lemak pada Pembuatan Kecap Lamtoro Gung(Leucaena leucocephala)

TerfermentasiAspergillus oryzae. Bioteknologi Vol 2: 14-20.

Samson, E.Y. and E.S. Hoekstra. 1988. Introduction to Food Borne Fungi. Crntralburen Voor Sckimmelculture Boarm Institute of TheRoyal : Netherlands Acaden $y$ of Art andSciences.

Suprapti, M.L. 2005. Kecap Tradisional. Kanisius: Yogyakarta. 